\title{
Parental Engagement in Children's Learning: Moving on from Mass Superstition
}

\author{
Janet Goodall \\ Department of Education, University of Bath, Bath, UK \\ Email: j.s.goodall@bath.ac.uk
}

How to cite this paper: Goodall, J. (2018). Parental Engagement in Children's Learning: Moving on from Mass Superstition. Creative Education, 9, 1611-1621. https://doi.org/10.4236/ce.2018.911116

Received: July 23, 2018

Accepted: August 28, 2018

Published: August 31, 2018

Copyright $\odot 2018$ by author and Scientific Research Publishing Inc. This work is licensed under the Creative Commons Attribution International License (CC BY 4.0).

http://creativecommons.org/licenses/by/4.0/

\begin{abstract}
In this article, I build on Goodman's concept of mass superstition, which he applied to the schooling system. Goodman holds that we continue to believe in the value of this system, without clear evidence that it is working. I use this concept to apply the argument to the way the current system deals with parents. In spite of clear indications in the research that parental engagement with children's learning is one of the best means to support educational achievement, particularly for children at risk of failure in the current system, parents are still routinely held at a distance from the learning processes fostered by the school system. I argue for a change to the foundational beliefs of the system, so that schools and families will work in partnership as co-constructors of children's learning.
\end{abstract}

\section{Keywords}

Parental Engagement in Children's Learning, Schooling Systems, Paul Goodman

\section{Introduction}

I have written elsewhere (Goodall, 2010) on the concept of superstition, not as a manifestation of ignorance or helplessness, but rather as a considered, human, rational response to a universe which is often perceived as capricious. It may well be true that we have come to understand the mechanisms by which large storms are created and distributed around the globe; however, when one experiences such things personally, the concepts of logic and scientific rigour seem more than a trifle unhelpful. Rather, we attempt to impose order, even when it seems that there is none. We do this by observation, reasoning and (hopeful) application: if $a$ follows $b \times$ number of times, it is logical to assume that it will continue to do so, even if there is no clear connection between the events. 
I have also written a good deal about the engagement of parents in the learning of their children (Goodall \& Vorhaus, 2011; Goodall, 2012; Goodall, 2013a; Goodall, 2013b; Goodall \& Montgomery, 2013; Goodall, 2014a; Goodall, 2014b; Goodall, 2015a; Goodall, 2015b; Goodall, 2015c; Goodall \& Johnston-Wilder, 2015a; Goodall \& Johnston-Wilder, 2015b). In this article, I intend to effect at least a betrothal, if not a marriage, between the concepts of superstition (as hopeful agency) and parental engagement. The minister of this union is Paul Goodman, particularly his work from the early 1970s, Compulsory Miseducation (Goodman, 1971); the acolyte to the marriage is Gramsci's concept of hegemony.

The link between Goodman's work and my own lies in his conceptualisation of the system of state funded education as "mass superstition". He is able to use this term because he relies on an older idea of superstition, which sees superstition as something that humans indulge in because they, in essence, don't know any better (Jarvis, 1980; Roud, 2006), as something that is believed without evidence, and as a valid term for something many (but clearly not all) believe and therefore few argue against.

Goodman sees our societal belief that children need to go to school to be educated as a mass superstition - a collective, unquestioned belief about not only the way things are but about the way they should and must be. Goodman sees the need for education, but seeks to de-couple that need from the system of schooling we have at the moment. He points out that many students feel entirely distanced from the processes of schooling but often shine in other areas. He suggests ways forward within the current system (such scrapping the process of grading at universities and that some universities could insist that prospective students spend at least two years "out in the world", as it were, before entrance) but overall, holds that the system we have now hinges on our superstitious belief that children and young people belong in schools rather than being able to learn in other ways.

On this, I would partially agree with him (Goodall, 2014c; Goodall, 2017); children and young people manifestly do not need to go to school to learn, or even to be educated, although both of these processes undoubtedly can and do take place in schools. I would even agree that children whom we deem to be of "school age" do not need the institution of schools; over 36,000 children in the UK are taught at home, for example (Jeffreys, 2015).

However, I do take issue with other ideas in Goodman's book. Goodman stops short of suggesting that the schooling system needs to be dismantled completely; rather, he suggests some wholesale changes to the system, and that some children and groups could opt out altogether. There is still merit in these ideas even more than 50 years after they were penned. I would propose a different and perhaps more radical solution to a system which is clearly not working well for all of its constituents, as there is a well-known and seemingly unmovable gap in achievement between children from different backgrounds (Save the Children, 2013). I would propose that we keep the framework and change the foundations on which it stands, that we move from a model in which has a clear disconnect 
between the different areas of children's lives, and move to a model of authentic partnership between families and schools.

More importantly, for superstition to be effective and ingrained, few people can realise that it would be possible to argue against these ideas. In this sense, superstitious belief could also be seen as hegemonic belief, based on the ideas of Antonio Gramsci. Gramsci used the concept of hegemony (which he never explicitly defined) to describe why individuals support a societal structure which does not benefit them (Lears, 1985),

The "spontaneous" consent given by the great masses of the population to the general direction imposed on social life by the dominant fundamental group; this consent is "historically" caused by the prestige (and consequent confidence) which the dominant group enjoys because of its position and function in the world of production (Gramsci et al., 1971: p. 145).

In essence, society, or rather, the people who make up a given society, have become convinced that the status quo is just the "way things should be"; "The values of the elite-in our case, the middle class-are internalised as simply the way things are, rather than being seen as elements of a system amenable to change" (Goodall, 2017).

Goodman styles teachers and other people working in and for the school system as "school monks"; I would, unfortunately, be listed among the "school-monks" (nuns?), as my livelihood as a lecturer in Educational Leadership most certainly depends on the existence and continuation of the system. My argument, which I believe to be true, that my interest in the system ultimately turns on improving the life chances of children, would cut no ice with Goodman; it's the system itself that is seen as the problem. He speaks of the "cult of schooling" in which I am, at the very least, an acolyte.

Goodman suggests that many young people react to the strictures of schooling $^{1}$ with "reactive stupidity", in which students either disengage from the system or begin to act out the anxieties, fears and anger which have been denied and repressed by the system. He goes on to point out that the ultimate end of the educative process should be enhancing the ability of young people to act wisely and well, on their own initiative (Goodman, 1971). This leads to an ever widening gap between the clerics of schooling and those whose conversion to the system they seek-particularly between the clerics and those who have actively rejected their baptism of scholasticism. This gap remains when students leave the schooling system (successfully or otherwise) as they become adults in the meta system which both produced and enforces the schooling regime (Bronfenbrenner, 1979). ${ }^{2}$

\footnotetext{
${ }^{1}$ It should be noted that I am not using "schooling" as a synonym for "education"; the first is a very small subset of the second.

${ }^{2}$ It could easily be argued that the monks of schooling form a subcultures parallel to that Goodman discovers among young people-we share a jargon, almost an entirely separate language, we contain within our ranks secrets or at least ideas not understood by people on the outside of the group.
} 
I take a different approach, assuming (as one would expect) that the system is salvageable. This doesn't mean that the system is not in need of a fairly radical (word used advisedly) overhaul. I've argued before that radical change is precisely what's needed (Goodall, 2014c), in the high old meaning of the word, signifying a return to one's roots. This too, is such an argument.

At its root, "education" links back to one of two Latin words, either educere, meaning to lead out or to train, or educare, meaning to train or to nourish (Frankena, 1973; Winch \& Gingell, 1999). There is a startling difference between the import of these words and the world of schooling as depicted by Goodman (or indeed, by Robinson in his well-known TED talk (Robinson, 2010)), who both present schooling as essentially static, with children in banks of rows, all learning the same material, at the same time, for the same embedded and ultimately incomprehensible reasons. This relates much more to the concept of training than to that of nourishing, or leading out of anything whatsoever. Schooling, as seen in these conception, uses what Freire called a banking model of education (Freire, 1970), in which knowledge is transferred more or less directly from teacher to student, with little input or even interest from the latter. (I would suggest that today, this picture is far more accurate a description of a university, rather than a school classroom). School, as well, derives from a root which presents a radically (sic) different scenario than that which takes place all too often. The word comes from an Old English root, which mean philosophy or lecture place (the second meaning might be closer to reality) (OED, 2016).

The original idea of education and schooling, then, was to support, to scaffold learning, in particular areas and for particular purposes (Sidorkin, 2011). And, to a great extent, we have returned to this idea, at least in relation to our children, in part due to the work of Goodman and others, who forced us (as a society) to reconsider how our children experience schooling. We have, as a society and as a system, moved much closer to Dewey's ideas of schooling as learning for life (Dewey, 1897; Dewey, 1916), and away from the regimented, rote based classroom against which Goodman, Freire and Montessori reacted. In this sense, I do not agree with Goodman that our schooling system represents a mass superstition, a societal belief in that which simply is not true. We have not yet achieved Goodman's ideal of mass education, which would be about educators passing on previous learning, and supporting criticality, with the aim of producing young people who would be able to function freely and well in society (Goodman, 1971).

This is not, however, an argument that the system is entirely fit for purpose, or serves all children equally well; while $22 \%$ of secondary schools are still being judged to require improvement or be inadequate (Ofsted, 2016), and while we still have large gap between children from different socio-economic backgrounds (Social Mobility and Child Poverty Commission, 2015), arguments for perfection, or even adequacy, of the system cannot be sustained.

I cannot agree that our schooling system is based on an essentially flawed idea 
or that it would not be possible to make it fit for the purposes we envision for it, that is, the mass schooling of our children and young people. This does not mean that we are superstition free in relation to schooling. We do not yet operate in a purely rational way, as much as we might like to believe this to be the case.

We have known for a good many years that parental engagement with children's learning represents one of the best ways to support children's learning in and out of school (Fan \& Chen, 2001; Desforges \& Abouchaar, 2003; Jeynes, 2007; Fan \& Williams, 2010; Jeynes, 2012); this case does not really need to be made yet again. When parents engage with their children's learning, particularly out of school, there are very likely to be increases in attendance, behaviour in school improves, homework return rates go up and, overall, children's achievement tends to improve (Fan \& Chen, 2001; Jeynes, 2007; Fan \& Williams, 2010; Goodall \& Vorhaus, 2011; Jeynes, 2012). This tends to be the case across groups not just among the middle classes, who already benefit well from the schooling system.

There is no need here to reproduce the arguments showing the value of parental engagement with children's learning. Rather, I wish to try to sift the discourse around the engagement of parents from engaging with schools (which is good but not as useful as other forms of engagement) to engagement with children's learning, which takes place mainly at home (or in the car, or on the bus...) (OECD, 2012; Goodall \& Montgomery, 2013).

When I speak to schools and school leaders about engaging parents, almost invariably I receive one bit of information and am asked one question: the percentage of parents who come to school for parents' evenings, is the information, and the question, in one form or another is, "how do I get the rest to come in?" This reflects a continuing belief-a superstition, if you will-that what is important is "getting parents in" or to put it more colloquially, "bums on seats".

I believe this amounts to a fairly clear case of superstition, a least according to the definition given above, as I shall demonstrate below in reference to the elements listed.

Merriam-Webster (Merriam-Webster, 2017) gives the following definition of superstition: "a belief or practice resulting from ignorance, fear of the unknown, trust in magic or change, or a false conception of causation"; I would argue that this definition is an accurate depiction of the schooling system, or more precisely, of an area of practice within the schooling system today, that area being the way that many school staff deal with the concept of parental engagement with children's learning.

\section{Ignorance}

The first of these elements is "ignorance", which might be better expressed as a gap between the research literature and practitioners in schools. While an increasing number of peer reviewed articles are available through open access 
routes, many still reside behind pay walls at least for a period of time. Add this to the heavy workload of teachers in England (Sellen, 2016), and it is hardly surprising that the results published in journals are not commonly accessed by school staff. The discourse of "hard to reach" parents and families has been roundly challenged in the literature (Lears, 1985; Crozier, 1999; Crozier \& Davies, 2007) but is still very common in schools (Campbell, 2011). Again, for a number of years, it has been known in the literature that the attitude toward learning in the home is of great importance, (Desforges \& Abouchaar, 2003; Sylva et al., 2008a; Sylva et al., 2008b) yet this is often missing in the school based discourse, which tends to centre around parents helping the school (Goodall, 2017). There is a gap, then, between common beliefs in schools-that the aim of parental involvement is to get parents into school-and the findings in the literature-that the aim should be to increase engagement in the home. I do not mean to suggest willful ignorance on the part of school staff, but it must certainly be acknowledged that the information from the research literature does not seem to be filtering through to school staff.

\section{Fear of the Unknown}

There is often a gap between parents and school staff in relation to experience, to social class, even to language. Parents have reported that school staff do not understand their families' context (Crozier, 1999; Crozier, 2001; Harris \& Goodall, 2008) and the literature has shown that interventions to support parents are more likely to succeed when they accord with parental values and mores (which is very difficult for school staff to arrange without knowledge thereof) (Goodall \& Vorhaus, 2011). Particularly in areas where parents face economic challenges, or do not come from the same background as school staff, this gap is likely to continue. Previous research has found that this lack of similar experience can lead to distrust between teachers and families (Crozier, 1999; Crozier, 2001).

There are at least two ways hegemony can be seen to be at play here. The first is the simple assumption which runs through this entire debate that the solution to the achievement gap is to be found in schools. Although work within schools clearly has not continued to narrow the gap, we continue to base our work there, simply because we rarely consider that there could be another way to approach the issue.

Secondly, due to the lack of diversity in the UK school teaching force, and the status of the schooling system as very much a part of the established order (schools are funded by and inspected by the state), it is perhaps understandable that hegemonic ideas of "what should be" pervade schools (Sue, 2004; Ule et al., 2015). This has been shown to apply to the area of parental engagement: there are ideas of what "good parenting" looks like, and who is capable of providing this. Parents who come from cultures which differ from those of the majority of teachers have found that their support for their children may be underappreciated or even disregarded (Crozier, 2001). Hegemonic ideas, almost by definition, are rarely questioned or even separated out as individual concepts; this ap- 
pears to be the case for how parental engagement is seen by many school staff. All of this adds up to a lack of knowledge and trust on both sides, so that neither parents nor school staff experience the other as partners, in supporting the learning of the child that they have in common.

\section{Trusting in Magic or Chance}

I would argue that our continued attempt to close the achievement gap and raise attainment by focusing on work in schools amounts certainly to superstition and in some ways to a belief in magic, or at the very least, to magical thinking. Magical thinking may be defined as "beliefs that defy culturally accepted laws of causality" (Einstein \& Menzies, 2004: p. 539). Even though the literature is clear that many of the mechanisms currently in use have little or no effect on what we're attempting to change (See \& Gorard, 2014; Huat See \& Gorard, 2015), we insist on continuing to apply such solutions.

It's often said that the definition of madness is to expect new outcomes from repeated actions; it may be that this particular form of madness is a form of magical thinking, or the other way around. What it most certainly is not, however, is either logical or, more importantly, effective for supporting our children's learning.

Politicians and policy makers, as well, continue to see schools as the locus of change. Schools are amenable to policy dictates, and accountable to outside bodies in a way that families are not, and unless our system changes radically, cannot be made to be. However, calls have already been made (Social Mobility and Child Poverty Commission, 2015) for the government to begin to move beyond schools and begin supporting and discussing family engagement with learning. There have been some moves in this direction such as the trial of a universal offer of parenting programmes (Lindsay et al., 2010; Cullen et al., 2013). However, these are aimed at the parents of pre-school children, which leaves the majority of children without this form of support.

We continue to ignore the most valuable lever to increase attainment and reduce the achievement gap, in favour of continuing to do things which are not working. Schools have done a very great deal (Save the Children, 2013) but the remaining gap needs a different solution. It is not clear why the findings of more than 20 years of research about the value of parental engagement which children's learning has for the most part been ignored in school processes and policies. It is easy to find proximal reasons, such as the lack of emphasis on this engagement in initial and continuing teacher training, but this still begs the question as to why it is not given more prominence.

It would seem likely that one explanation, perhaps the main one is a false concept of causation.

\section{A False Concept of Causation}

This brings me to the final element of the definition of superstition: a false conception of causation. In the usual run of superstition, this occurs when we 
attribute outcomes to inputs, when in point of fact the two are not causally connected, such as having good or bad luck after seeing a black cat cross our path.

In relation to parental engagement, the false causality is an assumed link between greater input by school staff, or changes in policy affecting school staff, between school staff and a narrowing of the achievement gap. The causal link here is missing; however dedicated and professional school staff may be, $80 \%$ of the achievement gape relates to issues outside the school gate (Rasbash et al., 2010). The link which must be made is that between parents and the learning of their children. As the research has made clear, it is here that we can begin to address, and to close, the achievement gap.

Almost two thirds of the British population rate themselves as at least mildly superstitions (Wiseman, 2003). When it comes to avoiding (or seeking out) particularly coloured felines during one's daily constitutional, such superstition is neither here nor there. We cannot, however, afford to continue to make decisions which affect the schooling of millions of children on the basis of ignorance, fear of the unknown, trust in magical ideas or the outcomes of false causality. We must go forward following a course based on rational thought and reliable research and move to support parental engagement with children's learning, especially for pupils at risk of under achievement.

We need to steer away from both the course of madness (expecting new results from old actions) and the imposition of actions which have little or no evidence base. Rather, we need to put into place actions which have been shown to be effective (Huat See \& Gorard, 2015). We are dealing with the educative and life chances of generations of children. They deserve not superstition, magical thinking and the works of madness, but rather logic, sense, and evidence based action.

In doing this, in taking account of the messages of research and putting them into practice, we can move from the older view of superstition given by Goodman, in relation to our schooling system, and move to a stance of hopeful human agency, of actions based on firm foundations. We still can't be absolutely certain of the outcome of particular interventions because each situation, each child is different. These differences have not, however, precluded great innovations in teaching to the benefit of students; I can only believe (on the basis of good evidence, rather than ignorance or flawed causality) that this will be the case if we, as a system, can move forward in supporting parents' engagement with their children's learning.

\section{Conflicts of Interest}

The author declares no conflicts of interest regarding the publication of this paper.

\section{References}

Bronfenbrenner, U. (1979). The Ecology of Human Development: Experiments by Nature 
and Design. Cambridge: Harvard University Press.

Campbell, C. (2011). How to Involve Hard-To-Reach Parents: Encouraging Meaningful Parental Involvement with Schools. Nottingham: National College for Teaching and Leadership.

Crozier, G. (1999). Is It a Case of "We Know When We're Not Wanted?" The Parents' Perspective on Parent-Teacher Roles and Relationships. Educational Research, 41, 315-328. https://doi.org/10.1080/0013188990410306

Crozier, G. (2001). Excluded Parents: The Deracialisation of Parental Involvement. Race Ethnicity and Education, 4, 329-341. https://doi.org/10.1080/13613320120096643

Crozier, G., \& Davies, J. (2007). Hard to Reach Parents or Hard to Reach Schools? A Discussion of Home-School Relations, with Particular Reference to Bangladeshi and Pakistani Parents. British Educational Research Journal, 33, 295-313. https://doi.org/10.1080/01411920701243578

Cullen, M. A., Cullen, S., Strand, S., Bakopoulou, I., Lindsay, G., Brind, R., Pickering, E., Bryson, C., \& Purdon, S. (2013). CANparent Trial Evaluation: First Interim Report. London: Department of Education.

Desforges, C., \& Abouchaar, A. (2003). The Impact of Parental Involvement, Parental Support and Family Education on Pupil Achievement and Adjustment: A Literature Review. London: Department of Education and Skills.

Dewey, J. (1897). My Pedagogic Creed. http://dewey.pragmatism.org/creed.htm

Dewey, J. (1916). Democracy and Education. London: The Macmillan Company. https://www.gutenberg.org/files/852/852-h/852-h.htm

Einstein, D. A., \& Menzies, R. G. (2004). The Presence of Magical Thinking in Obsessive Compulsive Disorder. Behaviour Research and Therapy, 42, 539-549.

https://doi.org/10.1016/S0005-7967(03)00160-8

Fan, W., \& Williams, C. M. (2010). The Effects of Parental Involvement on Students' Academic Self-Efficacy, Engagement and Intrinsic Motivation. Educational Psychology, 30, 53-74. https://doi.org/10.1080/01443410903353302

Fan, X., \& Chen, M. (2001). Parental Involvement and Students' Academic Achievement: A Meta-Analysis. Educational Psychology Review, 13, 1-22. https://doi.org/10.1023/A:1009048817385

Frankena, W. K. (1973). Education. In P. P. Wiener (Ed.), Dictionary of the History of Ideas: Studies of Selected Pivotal Ideas (p. 2). New York: Charles Scribner's Sons.

Freire, P. (1970). Pedagogy of the Oppressed. London: Penguin Books.

Goodall, J. (2010). Superstition and Human Agency. Implicit Religion, 13, 307-318. https://doi.org/10.1558/imre.v13i3.307

Goodall, J. (2012). Parental Engagement to Support Children's Learning: A Six Point Model. School Leadership \& Management, 33, 1-18.

Goodall, J. (2013a). Parental Belief and Parental Engagement: How Do They Interact? Journal of Beliefs \& Values, 34, 87-99. https://doi.org/10.1080/13617672.2013.759352

Goodall, J. (2013b). School-Home Communication: Texting. Bath: University of Bath.

Goodall, J. (2014a). Engaging Parents to Raise Achievement. School Leadership Today, $63,56-60$.

Goodall, J. (2014b). Re-Thinking Engagement. In Schools of Tomorrow (Ed.), Growing Engagement: Re-Imagining Relationships between Schools, Families and Communities (pp. 10-18). Peterborough: Schools of Tomorrow.

Goodall, J. (2014c). Re-Thinking Engagement. In Schools of Tomorrow (Ed.), Growing 
Engagement: Re-Imagining Relationships between Schools, Families and Communities (Vol. 2, pp. 11-19). Peterborough: Schools of Tomorrow.

Goodall, J. (2015a). Are Ofsted's School Inspections Leaving Parents at the Periphery?

Goodall, J. (2015b). Leading Parent Partnership Award Recertification-Results.

Goodall, J. (2015c). Ofsted's Judgement of Parental Engagement a Justification of Its Place in Leadership and Management.

Goodall, J. (2017). Narrowing the Achievement Gap: Parental Engagement with Children's Learning Creating a Learning-Centred Schooling System. London: Routledge.

Goodall, J., \& Johnston-Wilder, S. (2015a). Learned Helplessness and Maths Resilience. Bath: University of Bath.

Goodall, J., \& Johnston-Wilder, S. (2015b). Overcoming Mathematical Helplessness and Developing Mathematical Resilience in Parents: An Illustrative Case Study. Creative Education, 6, 526-535.

Goodall, J., \& Montgomery, C. (2013). Parental Involvement to Parental Engagement: A Continuum. Educational Review, 66, 399-410.

Goodall, J., \& Vorhaus, J. (2011). Review of Best Practice in Parental Engagement. London: Department of Education.

Goodman, P. (1971). Compulsory Miseducation. London: Penguin.

Gramsci, A., Nowell-Smith, G., \& Hoare, Q. (1971). Selections from the Prison Notebooks of Antonio Gramsci. New York, NY: International Publishers.

Harris, A., \& Goodall, J. (2008). Do Parents Know They Matter? Engaging All Parents in Learning. Educational Research, 50, 277-289. https://doi.org/10.1080/00131880802309424

Huat See, B., \& Gorard, S. (2015). The Role of Parents in Young People's Education-A Critical Review of the Causal Evidence. Oxford Review of Education, 41, 346-366.

https://doi.org/10.1080/03054985.2015.1031648

Jarvis, P. (1980). Towards a Sociological Understanding of Superstition in Les religions de la classe ouvrière. Social Compass, 27, 285-295.

Jeffreys, B. (2015). Rising Numbers of Pupils Home Educated. BBC News.

Jeynes, W. (2012). A Meta-Analysis of the Efficacy of Different Types of Parental Involvement Programs for Urban Students. Urban Education, 47, 706-742. https://doi.org/10.1177/0042085912445643

Jeynes, W. H. (2007). The Relationship between Parental Involvement and Urban Secondary School Student Academic Achievement: A Meta-Analysis. Urban Education, 42, 82-110. https://doi.org/10.1177/0042085906293818

Lears, T. J. (1985). The Concept of Cultural Hegemony: Problems and Possibilities. The American Historical Review, 90, 567-593. https://doi.org/10.2307/1860957

Lindsay, G., Strand, S., \& Cullen, M. A. (2010). Parenting Early Intervention Programme. 2nd Interim Report.

Merriam-Webster (2017). Superstition Merriam-Webster Online Dictionary.

OECD (2012). Let's Read Them a Story! The Parent Factor in Education. Paris: PISA, OECD Publishing.

OED (2016). School. Oxford English Dictionary.

http://www.oxforddictionaries.com/definition/english/school

Ofsted (2016). The Annual Report of Her Majesty's Chief Inspector of Education, Children's Services and Skills 2015/16. London. 
Rasbash, J., Leckie, G., Pillinger, R., \& Jenkins, J. (2010). Children's Educational Progress: Partitioning Family, School and Area Effects. Journal of the Royal Statistical Society: Series A (Statistics in Society), 173, 657-682. https://doi.org/10.1111/j.1467-985X.2010.00642.x

Robinson, K. (2010). Changing Education Paradigms.

Roud, S. (2006). The Penguin Guide to the Superstitions of Britain and Ireland. London: Penguin.

Save the Children (2013). Too Young to Fail. London: Save the Children.

See, B. H., \& Gorard, S. (2014). What Do Rigorous Evaluations Tell Us about the Most Promising Parental Involvement Interventions? A Critical Review of What Works for Disadvantaged Children in Different Age Groups. Nuffield Foundation.

Sellen, P. (2016). Teacher Workload and Professional Development in England's Secondary Schools: Insights from TALIS.

Sidorkin, A. M. (2011). On the Essence of Education. Studies in Philosophy and Education, 30, 521-527. https://doi.org/10.1007/s11217-011-9258-3

Social Mobility and Child Poverty Commission (2015). State of the Nation 2015: Social Mobility and Child Poverty in Great Britain. London: Social Mobility and Child Poverty Commission.

Sue, D. W. (2004). Whiteness and Ethnocentric Monoculturalism: Making the "Invisible" Visible. American Psychologist, 59, 761-769. https://doi.org/10.1037/0003-066X.59.8.761

Sylva, K., Melhuish, E. C., Sammons, P., Siraj, B. I., \& Taggart, B. (2008a). Final Report from the Primary Phase: Pre-School, School and Family Influences on Children's Development during Key Stage 2 (p. 165).

Sylva, K., Scott, S., Totsika, V., Ereky, S. K., \& Crook, C. (2008b). Training Parents to Help Their Children Read: A Randomized Controlled Trial. British Journal of Educational Psychology, 78, 435-455. https://doi.org/10.1348/000709907X255718

Ule, M., Živoder, A., \& du Bois-Reymond, M. (2015). "Simply the Best for My Children": Patterns of Parental Involvement in Education. International Journal of Qualitative Studies in Education, 28, 329-348. https://doi.org/10.1080/09518398.2014.987852

Winch, C., \& Gingell, J. (1999). Key Concepts in the Philosophy of Education. London: Routledge.

Wiseman, R. (2003). UK Superstition Survey. Hertfordshire: Psychology Department, University of Hertfordshire.

http://www.richardwiseman.com/resources/superstition_report 